CZU: 39(478)(092)

https://doi.org/10.52505/lecturi.2021.05.04

\title{
VICTOR CIRIMPEI: PROFIL ENCICLOPEDIC
}

\author{
Vlad CARAMAN \\ Institutul de Filologie Română „Bogdan Petriceicu-Hasdeu”, Chișinău
}

\begin{abstract}
Rezumat. Articolul cuprinde un portret enciclopedic al etnologului şi folcloristului român Victor Cirimpei. Membru al Uniunii Scriitorilor din Moldova, cercetător ştiinţific la Academia de Ştiinţe a Moldovei. A fost preocupat de etnofolclorismul secolelor XIX şi XX, precum şi de creaţia populară a românilor din zilele noastre.
\end{abstract}

Cuvinte-cheie: mitologie, etnologie, folclor, tradiţie, comic, activitate.

Abstract. The article contains an encyclopedic portrait of the Romanian ethnologist and folklorist Victor Cirimpei. Member of the Writers' Union of Moldova, scientific researcher at the Academy of Sciences of Moldova. He was preoccupied with the ethnofolklorism of the 19th and 20th centuries, as well as with the popular creation of today's Romanians.

Keywords: mythology, ethnology, folklore, tradition, comedy, activity.

Remarcabilul etnolog şi folclorist român Victor Cirimpei s-a născut la 15 februarie, 1940, în satul Drăgăneşti, judeţul Bălţi, România, a decedat la data de 11 martie, 2019, în Chişinău, Republica Moldova. Este fiul lui Alexandru Cirimpei şi Liza (Elisabeta Mândraji), ţărani. Între anii 1947 şi 1958 este elev la şcoala medie din satul natal. Apoi devine student la Facultatea de Istorie şi Filologie a Universităţii de Stat din Chişinău între 1958 şi 1964. După absolvirea universităţii ajunge doctorand la Institutul de Literatură Universală „A.M. Gorki”, (Academia de Ştiinţe a URSS), oraşul Moscova, anii 1965-1967. Totodată, din 1964 activează, în cadrul Academiei de Ştiinţe a Moldovei din Chişinău, în calitate de laborant delegat la doctorantură şi cercetător ştiinţific. Din 6 iunie 1968 devine doctor în filologie, cu teza Procese contemporane in folclor.

Victor Cirimpei a activat în calitate de redactor-secretar al ediţiei Creaţia populară moldovenească în 17 volume (1975-1983), a fost un timp redactor la „Revistă de lingvistică şi ştiinţă literară”, a iniţiat, organizat şi moderat mai mulţi ani simpozionul „Perenitatea creaţiei populare şi contemporaneitatea”.

Membru al Uniunii Scriitorilor din Moldova, a fost cercetător ştiinţific permanent mai mult de 50 de ani, începând cu august 1964, la Academia de Ştiinţe a 
Moldovei, inclusiv, din iulie 2006 până în februarie 2019, cercetător coordonator la Institutul de Filologie. La academie Victor Cirimpei a desfăşurat o vastă activitate în domeniul studierii valorilor etnofolclorice ale românilor, evoluţia şi transformările creaţiilor populare, influenţa lor asupra contemporaneităţii.

Graţie aportului adus în ştiinţă şi învăţământ pe parcursul activităţii sale domnia sa a fost decorat cu insigna „Eminent al Învăţământului Public din RSS Moldovenească", de două ori $(1989,1990)$. A fost distins cu premiul republican cultural „Dacia” al Centrului Naţional de Creaţie Populară (1990). Laureat al premiului „Simion Florea Marian” al Academiei Române (1995). Medalia Academiei de Ştiinţe a Moldovei „Dimitrie Cantemir” (2010).

Începând cu anii de şcoală Victor Cirimpei culege materiale etno-folclorice de la consăteni, apoi, ca student şi profesor şcolar din alte diferite localităţi din Basarabia, Bucovina, Transnistria. Mai apoi - ca laborant şi cercetător ştiinţific la academie - de la românii din Basarabia, Ucraina, Rusia, Georgia, Caucaz, publicând materialele în diverse volume-culegeri, antologii precum Frumos e la şezătoare, Crestomaţie de folclor moldovenesc, Genuri şi specii folclorice şi Relaţii folclorice moldo-ruso-ucrainene (1972).

Deosebit de preţioase sunt studiile cercetătorului despre mitologie (geneza indo-europeană a unor mituri, credinţe), etno-folcloristică (raportul dintre tradiţie şi contemporaneitate) şi interpretările literare (figuri emblematice ale literaturii şi culturii româneşti), studii care încep a vedea lumina tiparului pe la mijlocul anilor '60, întâi în publicaţii de profil din Chişinău, apoi la Moscova, Mahacikala, Câmpulung Moldovenesc, Bucureşti, Berlin etc.

Cercetătorul Alexandru Burlacu identifică următoarele direcţii principale de investigaţie ştiinţifică ale etnologului care sunt legate de: zămislirea şi evoluţia gândirii mitologice şi folclorice; cultura etnologică a românilor în context universal; istoria folcloristicii româneşti; natura şi funcţionarea comicului popular; interferenţele folclorului cu literatura; fenomenul artistic literar; editarea ştiinţifică a monumentelor de creaţie populară $(2010$, p. 5).

Din cele peste 200 de lucrări, publicate de C. pe parcursul anilor, 6 cărţi tratează monografic: 1) caracteristica evoluţiei contemporane a folclorului (Фольклор $и$ современность, Folclorul şi contemporaneitatea 1974), 2) contribuţia cronicarului Ion Neculce, pentru sec. XVII-XVIII, şi cea a pedagogului Teodor Stamati (sec. XIX) la consemnarea masivă a creaţiilor mitologice, etnografice şi de folclor (Realizări ale folcloristicii timpurii moldoveneşti, 1978), 3) specificul naraţiunilor comice româneşti (Snoave şi anecdote, 1979), 4) probleme de mitologie autohtonă, comic popular narativ, prefolcloristică şi folcloristică (în calitate de coautor al cursului teoretic universitar Creaţia populară (Curs teoretic de folclor românesc din Basarabia, Transnistria şi Bucovina), 1991), 5) etnicitatea basarabenilor (Argumente 
Basarabe. Dovezi referitoare la sigiliul românesc al dinastiei domnitorilor Basarabi in spaţiul dintre Prut şi Nistru, 2006), 6) specificul comicului artistic (Comicul folcloric, literar, politic-naţional, 2013) (Burlacu, 2010, p. 5).

Altele 5 sunt volume de cercetări şi materiale etno-folclorice: Ace pentru cojoace. Glume, anecdote, snoave (1985); Păcală şi Tândală, cu ediţii aparte în franceză, engleză, spaniolă (1987) şi rusă (1991); Soare nou răsare. Folclor al sărbătorilor de iarnă (1990); Pozne cu alde Păcală. Povestiri şi dialoguri din folclorul comic românesc (2007); Pătăranii folclorice ale românilor sovietici din Basarabia, stânga Nistrului, nordul Bucovinei, nordul Transilvaniei, Caucazul de vest (2008) (Burlacu, 2010, p. 5).

În general etnologul însumează articole şi studii proprii în peste 20 de cărţi-culegeri, iar ca şi coautor este prezent în peste 15 astfel de lucrări cu texte folclorice selectate şi comentate, precum: Folclor din Bugeac (1982), Folclor din nordul Moldovei (1983), Frumos e la şezătoare (1983), Folclor din stepa Bălţilor (1987), Folclor din Maramureş (1991), Folclor din Ţara Fagilor (1993), Cât îi Maramureşul (1993) Dimitrie Cantemir şi Moldova din stânga Prutului, Dimitrie Cantemir [despre] plaiul natal şi datinile sale (2008) etc.

Victor Cirimpei, în colaborare, a lucrat şi la elaborarea unui manualcrestomaţie de Literatura română pentru clasa a VII-a pentru şcoala naţională.

Despre cărţile şi cele circa 200 de studii şi articole ştiinţifice, publicate pe parcursul anilor, s-a vorbit în nenumărate rânduri şi cu diferite ocazii. Şi el, la rândul său, a avut în vizorul criticii sale personalităţi notorii despre care a scris bine documentat, cu multă perspicacitate şi prezenţă de spirit. Remarcăm aici următoarele studii: Vasile Coroban - culegător şi cercetător de folclor; Sergiu Moraru - neobosit cercetător şi propagator al valorilor folclorice (1946-1996); Soare nou răsare: Folclor al sărbătorilor de iarnă (Texte în versuri); Iordan Datcu. Etnologi basarabeni, nord-bucovineni şi transnistrieni; Iulian Filip - omul, poetul, folcloristul; Vladimir Beşleagă: Cultura populară, comicul realităţii, naturalețea limbajului; Fenomenul complex neordinar Iulian Filip; Vasile Toma, sarcastic, E. Baican, Literatura populară sau Palavre şi anecdote, 100 subiecte; Nichita P. Smochină: un distins etnolog român, scos din anonimat ş.a.m.d.

Cele mai prestigioase reviste şi ziare de specialitate de la noi şi de peste hotare îi găzduiesc anual studii preţioase între care remarcăm Folclorul comic şi puterea; Fragmente de tezaur al mentalităţii şi inteligenței populare; Dragoste de mamă gen Roland Barthes/ Grigore Vieru; Esenţa surselor şi structura cercetării „, Gândirea comică populară”; Principiile directorii de documentare şi editare a materialelor arhivistice de etnologie orală românească din Republica Moldova; Vocabulă tracică pe parcurs de milenii; Relații dintre popoare în folclorul comic 
românesc; Particularităţi ale eticii relaţiilor socioculturale dintre popoare în folclorul comic românesc; Datina arderii unei buturugi la solstitiul de iarnă; Reflexe de vorbă tracică pe parcurs de milenii în limbile diferitor popoare. E prezent cu astfel de cercetări în reviste şi ziare precum Revistă de lingvistică şi ştiinţă literară, Metaliteratură, Philologia, Francopolyphonie, Limba română, Literatura şi arta, Glasul naţiunii, Tara, Timpul etc.

Victor Cirimpei a fost un împătimit al mitologiei şi folclorului, a fost un asiduu cercetător ştiinţific, un aprig apărător al adevărului istoric şi ştiinţific care s-a bucurat, la rândul său, de o înaltă apreciere în critica literară de la noi şi din Ţară. Remarcăm îndeosebi aici pe cercetătorii Mihai Cimpoi, Ion Oprişan, Andrei Hâncu, Ion Filipciuc, Iordan Datcu, Iulian Filip, Alexandru Burlacu, Marcu Gabinschi, Mariana Cocieru etc., care în exegezele lor au pus în valoare noutatea şi profunzimea investigaţiilor unui etnolog de aleasă şi temeinică şcoală gen Vasile Coroban, Ovidiu Bârlea, I. C. Chiţimia, Eugen Russev.

SCRIERI: Фольклор и современность (Folclorul şi contemporaneitatea), Chişinău, 1974, (în limba rusă); Realizări ale folcloristicii timpurii moldoveneşti, Chişinău, 1978; Snoave şi anecdote, Chişinău, 1979; Ace pentru cojoace. Glume, anecdote, snoave, Chişinău, 1985; Păcală şi Tândală, cu ediţii aparte în franceză, engleză, spaniolă (1987) şi rusă (1991); Soare nou răsare. Folclor al sărbătorilor de iarnă, Chişinău, 1990; Argumente Basarabe. Dovezi referitoare la sigiliul românesc al dinastiei domnitorilor Basarabi în spaţiul dintre Prut şi Nistru, 2006; Pozne cu alde Păcală. Povestiri şi dialoguri din folclorul comic românesc Chişinău, 2007; Pătăranii folclorice ale românilor sovietici din Basarabia, stânga Nistrului, nordul Bucovinei, nordul Transilvaniei, Caucazul de vest, Chişinău, 2008; Comicul folcloric, literar, politic-naţional, Chişinău, 2013.

Din volume colective: Frumos e la şezătoare; Crestomaţie de folclor moldovenesc; Genuri şi specii folclorice; Relaţii folclorice moldo-ruso-ucrainene; Cântece revoluţionare şi sovietice; Creaţia populară (Curs teoretic de folclor românesc din Basarabia, Transnistria şi Bucovina); Folclor din Bugeac; Folclor din nordul Moldovei; Frumos e la şezătoare; Folclor din stepa Bălţilor; Folclor din Maramureş; Folclor din Ţara Fagilor; Cât ăi Maramureşul...

Repere bibliografice: Al. Donos, Creaţia populară astăzi, „Cultura”, 1974, 21 decembrie; Gr. Bostan, Din tezaurul culturii populare, „Zorile Bucovinei”, 1975, 24 decembrie; E. Russev, Corelaţia folclor-cronografie, „Nistru”, 1978, nr. 8; A. Hâncu, ,O samă de cuvinte”, Literatura și arta, 1978, 14 septembrie; E. Junghietu, S. Moraru, Noi volume din seria „Creația populară moldovenească”, „Nistru”, 1982, nr. 9; Chiţimia Ion. C., Realizări ale folcloristicii timpurii moldoveneşti; O. Bârlea, Limba şi literatura. Vol. II, Buc. 1983; Mircea Fotea, Simeon Florea Marian-folclorist şi etnograf, Bucureşti, 1987; I. Datcu, Soare nou răsare. Revistă 
de etnografie şi folclor. Buc., 1992, nr. 1.; M. Gabinschi, V.C. Revistă de lingvistică şi ştiinţă literară, 1996, nr. 4; Al. Dobre, V.C. Revistă de etnografie şi folclor, 1996, vol. 41, nr. 3-4; Gr. Bostan, V.C. Poezia populară românească în spaţiul carpatonistrean, Iaşi, 1996; I. Datcu, Dicţionarul etnologilor români, Buc., 2006. I. Ciocanu, Etnolog implicat adânc în cunoaşterea istoriei şi limbii. Philologia, ianuarie-aprilie, 2010; Iu. Filip, Pe un tărâm cu ne-nţelesuri multe. Philologia, ianuarie-aprilie, 2010; V. Toma, Harnicul cercetător-etnolog Victor Cirimpei. Philologia, ianuarie-aprilie, 2010; A. Pasat, Victor Cirimpei - ca cercetător al comicului popular. Philologia, ianuarie-aprilie, 2010; Al. Burlacu, Un fenomen complex: Victor Cirimpei: [70 de ani de la naşterea cercetătorului folclorist]. Literatura şi arta, 11 februarie, 2010; M. Cimpoi, De cel cine şi cum râdem, 2013; Iu. Filip, Autoportret mozaical Dr. Victor CIRIMPEI la 75 de ani, Chişinău, Akademos, nr. 1, 2015; V. Caraman, Elogiu lui Victor Cirimpei: [portretul etnologului la 75 de ani]. Literatura şi Arta, 12 februarie, 2015; M. Cocieru, Dimensiuni diacronice ale mitologiei autohtone în studiile ştiinţifice ale lui Victor Cirimpei. Realităţi Culturale, nr. 5, 2015; M. Cocieru, Victor Cirimpei - contribuţii la cercetarea mentalului mitologic românesc. Philologia, mai-august, 2020.

Şi iată câteva referinţe concrete care justifică valoarea ştiinţifică a studiilor lui V.C.

M. Cimpoi, De ce/ cine şi cum râdem, 2013 „Ce surprinde în cartea reputatului etnolog Victor Cirimpei? Bineînţeles, faptul că ştie multe, dacă nu chiar totul, despre problema discutată sub toate aspectele pe care le relevă: geneză, istoric, definiţia estetică a conceptului, genuri, specii, semnificaţia de manifestare umană, de marcă fenomenologică a spiritului, figuri comice, po(i)etică şi toate celelalte. Victor Cirimpei este un om de ştiinţă veritabil, deci dedicat cu trup şi suflet... ştiinţei...

E un studiu exhaustiv care ne ajută să înţelegem toate aspectele râsului popular şi ale celui cult, răspunzând imperativului integraţionist: cum ne încadrăm cu cultura noastră, inclusiv cu umorul nostru subtil, bonom, de înaltă calitate estetică, în cultura universală" (Cimpoi, 2013, p. 10).

Iu. Filip, Pe un tărâm cu ne-nţelesuri multe. Philologia, ianuarie-aprilie, 2010. „Diapazonul ispitelor ştiinţifice ale lui Victor Cirimpei sensibilizează şi ilustrează nuanţat categoria cercetătorului complex (dacă nu cumva integru) şi a motivului aşa-zisului stil ştiinţific (care adeseori e un fals motiv), ademenindu-ne într-un câmp polemic, din care nu e atât de uşor de ieşit. Cert e că cercetătorul Cirimpei, ispitit şi de critică literară şi scriitura modernă, pe lângă preocupările sale constante pentru Dimitrie Cantemir, Ion Neculce, B. P. Hasdeu, comicul popular; cu investigaţii în mitologie şi etnologie, în istoria geto-dacilor, dispune - până la urmă - de altfel de instrumente decât specializatul îngust, dispune de flexibilităţi 
transfrontaliere-interdisciplinare, care-i înlesnesc (vorba poeziei mele) întregirea ulciorului cu cioburile din diferite domenii de cercetare" (Filip, 2010, p. 132).

M. Cocieru, Victor Cirimpei - contribuţii la cercetarea mentalului mitologic românesc. Philologia, mai-august, 2020. „Demersul întreprins asupra dimensiunii mitologiei autohtone analizate în studiile etnologului Victor Cirimpei ne justifică să afirmăm că exegetul etnolog a dat dovadă permanent de vervă şi curaj în a investiga subiecte aflate în obscuritate, lipsite de atenţia cercetătorilor sau neanalizate până la capăt, reuşind în felul acesta să aducă mai multă claritate, păstrând imparţialitate pentru cele descoperite şi punând accent nemijlocit pe adevărul istoric şi documentar" (Cocieru, 2020, p. 90).

P.S. Pe parcursul activităţii sale de mai bine de o jumătate de secol etnologul s-a aflat mereu în căutarea perlelor creaţiei populare, acumulând un vast material folcloric. Din păcate, o altă bună parte din materialul selectat a rămas în arhiva personală a cercetătorului, nefiind valorificat, urmând, sperăm, să vadă eventual lumina tiparului în condiţii mai prielnice...

\section{Referințe bibliografice:}

1. BURLACU, Alexandru. Un fenomen complex: Victor Cirimpei: [70 de ani de la naşterea cercetătorului folclorist]. Literatura şi arta, 11 februarie, 2010.

2. CARAMAN, Vlad. Elogiu lui Victor Cirimpei: [portretul etnologului la 75 de ani]. Literatura şi Arta, 12 februarie, 2015.

3. CIMPOI, Mihai. De cel cine şi cum râdem. Prefaţă la cartea Comicul folcloric, literar, politic-naţional, Chişinău, 2013.

4. COCIERU, Mariana. Victor Cirimpei - contribuţii la cercetarea mentalului mitologic românesc. Philologia, mai-august, 2020.

5. Dicţionarul scriitorilor români din Basarabia 1812-2006, Chişinău, Prut Internaţional, 2007.

6. FILIP, Iulian. Pe un tărâm cu ne-nţelesuri multe. Philologia, ianuarie-aprilie, 2010.

Notă: Articolul a fost realizat în cadrul proiectului de cercetare 20.80009.1606.03 Contexte socioculturale autohtone şi interconexiuni europene în creaţia populară şi literatura cultă din Basarabia (sec. XIX până în prezent), Institutul de Filologie Română „B. P.-Hasdeu” al MEC 